\title{
ОСНОВИ ФОРМУВАННЯ ЛЬВІВСЬКОЇ БАЯННОЇ ШКОЛИ В КОНТЕКСТІ ВИКОНАВСЬКОЇ ТРАДИЦІЇ (ТЕРМІНОЛОГІЯ, ТИПОЛОГІЯ, ОСОБЛИВОСТІ РЕГІОНАЛІСТИКИ)
}

\author{
Кундис Р. Ю., Душний А. І., Зав'ялова О. К.
}

\section{ВСТУП}

Формування традицій львівського осередку баянно-акордеонного мистецтва у сфері виконавства, педагогіки та творчості має порівняно недавню історію. Проте його становлення позначене стрімкістю та помітною результативністю, що зробило регіональну школу Львова вагомою складовою частиною української академічної школи народноінструментального мистецтва. Підвалини іiі гнучкої педагогічної концепції започатковані корифеями: М. Оберюхтіним та його послідовниками - А. Онуфрієнком і Е. Мантулєвим. Цими музичними діячами закладено та створено передумови розбудови багаторівневої мережі фахового викладання гри на баяні в музичних навчальних закладах. У них пройшли важливі стадії мистецького формування низка високопрофесійних музикантів: лауреатів міжнародних, республіканських та всеукраїнських конкурсів, науковців, композиторів, громадських діячів та керівників музично-навчальних закладів, керівників оркестрів та диригентів.

На Львівщині, в одній з областей України, що має особливо велику кількість музично-мистецьких та музично-педагогічних навчальних закладів із баянними класами, продовжують викладацьку діяльність іiї кращі фахівці. Вони, у свою чергу, виховують нові покоління, тим самим засвідчують значущість традицій самобутньої баянної школи, формують власну педагогічну концепцію розбудови багатоступеневої системи фахового викладання.

Особливе визнання осередок баянного мистецтва здобув на зламі XX-XXI століть після започаткування А. Душним, С. Карасем, Б. Пицом проєкту «Львівська баянна школа» ${ }^{1}$ (2005 рік), який став

\footnotetext{
${ }^{1}$ Пиц Б., Душний А. Науково-мистецький проєкт «Львівська баянно-акордеонна школа» у контексті баянно-акордеонного руху Західної України. Музикознавчі студї інституту мистеитв Волинського національного університету імені Лесі Украӥнки та Національної музичної академії Украӥни ім. П. Чайковського : збірник наукових праць / упоряд. О. Коменда. Луцьк : Волин. нац. ун-т ім. Лесі Українки, 2011. Вип. 8. С. 47-58.
} 
потужним каталізатором баянного руху Львівщини та всієї України і дедалі більш упевнено виходить на міжнародну арену.

Джерелознавчою базою дослідження постають роботи українських музикознавців, пов'язані 3 питаннями вітчизняного баянного мистецтва, які охоплюють значне коло методичних, історичних, виконавських проблем, серед них: узагальнювальні праці 3 історії української школи народно-інструментального мистецтва М. Давидова, Є. Іванова, А. Сташевського, А. Семешка; праці історичного спрямування та довідниково-енциклопедичні видання М. Імханицького, довідники А. Басурманова, А. Семешка, А. Душного та Б. Пица, словник I. Лисенка; матеріали конференцій («Львівська баянна школа та іiі видатні представники»; «Академічне народно-інструментальне мистецтво та вокальні школи Львівщини»; «Творчість композиторів України для народних інструментів»; «Народно-інструментальне мистецтво на зламі XX-XXI століть»); дослідження окремих мистецьких явищ та розкриття персоналій-представників осередку баянного мистецтва Львівщини: А. Батршина, А. Боженського, В. Балика, В. Власова, В. Голубничого, А. Душного, С. Карася, Д. Кужелєва, Р. Кундиса, Е. Мантулєва, М. Оберюхтіна, А. Онуфрієнка, Я. Олексіва, Г. Олексів, Б. Пица, Л. Посікіри, М. Паньківа, М. Римаренка, Г. Савчин, О. Сергієнко, А. Славича, В. Суворова, Н. Сторонської, І. Фрайта, М. Черепанина, Ю. Чумака, А. Шамігова, В. Шафети, О. Якубова, В. Янчака й інших.

\section{1. Термінологічна основа дослідженості феномену виконавської школи}

Культурологічні дослідження А. Алексєєва, Н. Терентьєвої, В. Чинаєва й інших трактують поняття школи у широкому узагальнювальному сенсі як частину культурного простору конкретної історичної епохи. Загальнофілософське трактування поняття: «<...> школа (у мистецтві) - це художній напрям, течія, представлена групою учнів і послідовників, об’єднаних спільними творчими принципами» ${ }^{2}$. На підставі низки праць, у яких окреслена проблематика фігурує як дотична (С. Бойко, В. Гасілов, Д. Зербіно, Б. Кедров, Г. Лайтко, Л. Салямон, Б. Фролов, Г. Штейнер, М. Ярошевський), поняття виконавської школи позиціонується як «особливий тип комунікації, що здійснюється в синкрезисі двоєдиного процесу творення і навчання у творчій діяльності» ${ }^{3}[34$, с. 7].

2 Школа (в искусстве). Большая советская энциклопедия. Т. 48. С. 82. URL: http://slovari.yandex.ru.

3 Дедусенко Ж. Виконавська піаністична школа як рід культурної традиції: автореф. дис. ... канд. мистецтвозн.: 17.00.01. Київ, 2002. С. 7. 
Чимало праць присвячено вивченню характерних рис окремих інструментальних чи національних виконавських шкіл. Серед них роботи таких авторів, як: М. Давидов (українська академічна школа народноінструментального виконавства), Д. Кужелєв (проблематика української баянної школи, національного академічного баянного виконавства та творчості), В. Чабана («Білоруське баянне мистецтво: формування академічної виконавської школи»).

Найбільш широким за обсягом напрацювань та глибиною засвоєння традиції є поняття «національна школа». В. Чабан характеризує ознаки національної баянної школи Білорусі й окреслює іiі мету як осягнення виконавського методу, засіб формування аналітичної культури музикантавиконавця (що $\epsilon$ істотним показником школи), свободу оперування методологією виконавського аналізу музичних творів. Сама школа, на думку автора, представлена як «ефективний механізм усебічного його розвитку й інтеграції баяна в систему розвинених класичних музичних інструментів» ${ }^{4}$.

Виконавську школу як об'єкт музикознавства вивчала Віра Сумарокова, яка трактує іï через систему позицій, методів і методики, тобто через традиції виховання та навчання музичного професіоналізму через дидактичний пошук, акумулювання, розвиток або реформування академічних форм викладання, актуалізацію i підвищення якості підготовки майбутніх спеціалістів ${ }^{5}$.

Щодо баянного академічного мистецтва, то схожі аспекти розглядаються в окремих узагальнювальних працях 3 історії української школи народно-інструментального мистецтва М. Давидова, Є. Іванова, А. Сташевського, А. Семешка, також у наукових роботах історичного спрямування та довідниково-енциклопедичних виданнях: М. Імханицького, у довідниках А. Басурманова, А. Семешка, словнику I. Лисенка.

Звернемо увагу на стабільну наявність, єдність і взаємодію двох компонентів музично-мистецької школи - це виконавський та педагогічний. Перший поєднує в єдиний комплекс спільні принципі підготовки у процесі роботи над програмою загалом та специфічні закономірності інтерпретації окремих композицій у передконцертний період, пріоритети в царині репертуарної політики, інтенсивність i географічні межі концертування й гастролювання, наявність та

4 Чабан В. Белорусское баянное искусство: формирование академической исполнительской школы. Минск : БГАМ, 2008. С. 9.

5 Сумарокова В. Виконавська школа як об'єкт дослідження : до визначення поняття. Науковий вісник Наиіональної музичної академії імені П.І. Чайковського: Музичне виконавство / ред. : М. Давидов, В. Сумарокова. Київ, 2002. Вип. 40. C. $180-190$. 
масштаби здобутків у виконавських конкурсах, представництво виконавської майстерності та визначних здобутків композиторської творчості на національному та міжнародному рівнях. Другий включає наявність досягнень у сфері підготовки як виконавців-інтерпретаторів, так і педагогів, організацію найрізноманітніших форм мистецького життя, удосконалення та розбудову фахово-освітньої системи, формування багажу методико-педагогічних напрацювань, які стають константними в межах регіону з подальшим виходом на національний та міжнародний рівень.

У діяльності провідних представників інструментальних шкіл ми бачимо зазвичай поєднання обох складників в одній іпостасі: напрацювання, сформовані на підставі власної виконавської практики 3 високими мистецькими здобутками, у процесі педагогічної діяльності засвоюються і примножуються представниками класу (послідовникам школи універсалізм самовияву притаманний різною мірою), із часом осмислюються й узагальнюються в методичних працях, репертуарних збірниках, музично-критичних та публіцистичних нарисах, наукових дослідженнях, дають поштовх для розвитку та виникнення нових форм концертного та педагогічного життя.

Т. Баран розділяє поняття виконавської та педагогічної школи, у монографічній праці він констатує значущість саме регіональних осередків: «<..> Об'єднувальним фактором у становленні академічного професіоналізму стало формування дидактичних підходів у певному етнокультурному просторі та виокремлення ряду педагогічних та виконавських шкіл, роль яких $\epsilon$, без сумніву, визначальною для всіх еволюційних процесів - як технологічного, так і мистецького характеру» ${ }^{6}$.

Сучасне українське музикознавство дедалі докладніше розробляє дефініцію, понятійний апарат, систему типологічних ознак та класифікацію виконавських шкіл. Саме визначення поняття, його змістове наповнення, ознаки, структура, коло функцій істотно відрізняються у працях різних дослідників, що свідчить про пошук і активне формування найбільш відповідного наукового апарату, категоріального, термінологічного, типологічного тощо.

Термін «виконавська школа» стосується проблематики теорії й історії інструментального виконавського мистецтва, методики, педагогіки, культурології, музичної соціології, він широко застосовується у фаховій літературі та наукових розвідках, що свідчить про актуальну потребу окреслення певного кола явищ і наявність загальних закономірностей, які зумовлюють його застосування. Він має велику шкалу видової диференціації:

\footnotetext{
${ }^{6}$ Баран Т. Цимбали та музичний професіоналізм. Львів : Афіша, 2008. С. 100.
} 
1. Як засіб диференціації специфіки історичних (наприклад: дорадянський період), стильових (романтичний, постмодерний), територіальних (європейський), національних, регіональних, фаховоосвітніх (консерваторія, відділ, кафедра), індивідуально-педагогічних ознак певної сукупності засобів, що зумовлюють інструментальне виконавство як вид мистецтва та рівень професіоналізму.

2. Як система напрацювань опанування i засвоєння принципів виконавства на інструментах певної групи (струнне, духове), певного виду (цимбальне, баянне) чи певної традиції (академічне, аматорське, автентичне).

3. Як зафіксований результат методичних напрацювань, теоретичних положень, методичних рекомендацій та дидактичного репертуару, що слугує матеріалом у співпраці наставника й учня (наприклад, «Школа гри на українських цимбалах» О. Незовибатька, «Школа джазу на баяні та акордеоні» В. Власова).

4. Як певна ланка чи етап фахової професіоналізації музикантапрофесіонала (початкова, середня, вища школа).

5. Як модель канону підготовки професіонала-виконавця (осмислення, реалізація в навчальному процесі через підготовку концертної діяльності).

У цьому контексті конкурсно-фестивальний рух та гастрольнокониертна діяльність слугують одними 3 найвагоміших критеріїв оцінки результативності педагогічної системи, методичних досягнень як окремих викладацьких класів, так i осередків плекання академічного інструментального професіоналізму. У музикознавстві ця проблематика висвітлена в різноплановій науковій літературі, зокрема мистецькі змагання баяністів-виконавців, їхні цілі, характер, перебіг, результати (у яких, зокрема, представлено баянні колективи Львівщини) представлені в довідникових виданнях А. Басурманова ${ }^{7}$, М. Давидова ${ }^{8}$, А. Семешка ${ }^{9}$, найбільшою мірою - А. Душного та Б. Пица ${ }^{10}$, у дисертаційному дослідженні Р. Безуглої ${ }^{11}$, посібниковому виданні В. Понікарової ${ }^{12}$, вони

7 Басурманов А. Баянное и аккордеонное искусство : справочник. Москва : Кифара, 2003. 540 с.

8 Давидов М. Виконавське музикознавство : енциклопедичний довідник. Луцьк : ВАТ «Волинська обласна друкарня», 2010. 400 с.

${ }^{9}$ Семешко А. Баянно-акордеонне мистецтво України на зламі XX-XXI століть : довідник. Тернопіль : Навчальна книга «Богдан», 2009. 244 с.

10 Душний А., Пиц Б. Львівська школа баянно-акордеонного мистецтва : довідник. Дрогобич : По́світ, 2010. 216 с.

11 Безугла Р. Баянне мистецтво в музичній культурі України (друга половина ХХ століття) : автореф. дис. ... канд. мистецтвозн.: 17.00.03. Київ, 2004. 21 с.

12 Поникарова Л. Баян в народно-инструментальном жанре Украины : учебнометодическое пособие по курсу «Теория и история народно-инструментального исполнительства». Харьков : Торнадо, 2003. 104 с. 
фігурують у виданнях, присвячених окремим навчальним закладам регіону $^{13}$, матеріалах низки тематичних науково-практичних конференцій (зокрема, присвячених формуванню та реалізації комплексу ознак Львівської баянної школи), в інтерв'ю-повідомленнях низки популярних періодичних видань.

Досить нестабільним і не завжди точним у трактуванні залишається поняття авторської виконавської школи, насамперед через функціональні ознаки. Це свідчить про актуальність обраної проблематики та необхідність випрацювання й обгрунтування генеральних критеріїв.

У словнику С. Гончаренка «авторська школа» визначається як «<..> оригінальна загальнопедагогічна, дидактична, методична чи виховна система, опрацьована з урахуванням надбань психології, педагогіки, вікової фізіології та інших наук, вітчизняного й зарубіжного досвіду, яка реалізується під керівництвом чи за участю їі автора (авторів) принаймні в одному навчально-виховному закладі (наприклад, школа В.О. Сухомлинського, школа М.П. Гузика та інші)» 14 .

Переконливе визначення поняття пропонує О. Юрченко, стверджує, що авторська школа «<..> передбачає існування конкретної особи зяскравими індивідуальними стильовими рисами, ii попередників і послідовників. У даному разі важлива саме особистісна передача виконавської майстерності, потужний творчий імпульс» ${ }^{15}$. За визначенням В. Сумарокової, авторська школа - феномен, у якому об'єднуються загальнонаціональні, історичні, культурні, регіональні традиції 3 індивідуальним, авторським началом ${ }^{16}$.

${ }^{13}$ Гордельянов I. Дрогобицьке музичне училище ім. В. Барвінського. Історія виконавства на народних інструментах (украӥнська академічна школа) : підручник для вищих та середніх музичних навчальних закладів / М. Давидов. Київ : НМАУ ім. П. Чайковського, 2005. С. 357-360 ; Кужелєв Д. Кафедра народних інструментів. Сторінки історії Львівської державної музичної академії ім. М. Лисенка. Львів : Сполом, 2003. С. 179-189 ; Львівське державне музичне училище імені Станіслава Людкевича. Сторінки історії / ред.-упоряд. Н. Пузанкова. Львів : ТеРус, 2009. 216 с.; Мазепа Л., Мазепа Т. Шлях до музичної Академії у Львові : у 2-х т. Львів : Сполом, 2003. T. 1.288 c.

14 Гончаренко С. Авторська школа. Украӥнський педагогічний словник / С. Гончаренко. Київ : Либідь, 1997. С. 14-15.

${ }^{15}$ Юрченко О. Елена Костенко - основательница цимбальной исполнительской школы Слобожанщины. Проблеми взаємодії мистецттва, педагогіки та теорії і практики освіти : Постать мития у художньому просторі міста : збірник наукових праць / ред. та упоряд. Л. Шаповалова. Харків, 2009. Вип. 24. С. 113-122.

${ }_{16}$ Сумарокова В. Виконавська школа як об'єкт дослідження : до визначення поняття. Науковий вісник Національної музичної академії імені П.І. Чайковського: Музичне виконавство / ред. : М. Давидов, В. Сумарокова. Київ, 2002. Вип. 40. C. $180-190$. 
На кожному з рівнів різними способами реалізуються основні функції школи: пізнавальна, комунікативна та дидактична. Пізнавальна функція спрямована на підсумування й осмислення творчого, методичного, педагогічного, пізнавального, виховного досвіду через створення навчальної літератури, репертуарних збірників, самовияв через інтерпретацію і композицію, інші види творчої діяльності. Комунікативна та дидактична функції полягають у відборі та розбудові дидактично вивіреної системи передачі та засвоєння знань, співпраці педагога й учня над етапами підготовки концертного виконання, формуванні в цьому процесі творчої особистості молодого музиканта, вихованні емоційної, художньої, інтелектуальної, технічної та виразової сфер, спрямованих на виконавський процес.

Отже, утворюється симетрична система: педагог-наставник, який пройшов стадію формування в лоні певної виконавської та навчальної традиції, творчо переосмислив іiі, доповнив власним практичним виконавським досвідом та навичками, набутими у процесі інших видів діяльності (організації, керівництва, участі в колективах, ініціювання концертного виконавства, наукової, методичної, публіцистичної, фольклористичної, композиторської діяльності), з одного боку, і учень, для якого взірцем слугує мистецька позиція, методична система та виконавський приклад педагога, $є$ визначальними його методи творчої та технічної роботи, які в майбутньому проєктуються на власний стиль творчої та педагогічної діяльності, свідомо обраний соціальний статус i громадянську позицію.

Педагог, що представляє колектив, об'єднаний спільністю дидактичних, технічно-виконавських та художньо-інтерпретаційних завдань, постає як представник певної школи. У такому разі «учитель немов персоніфікує спадок соціуму, $є$ носієм знання i непорушним авторитетом» ${ }^{17}$. Яскраве авторське начало виступає динамічним елементом цієї системи, засобом збагачення закріплених і сформованих традиції, спадку, внеску, наступності.

Отже, поняття авторської школи диференціюється як: освітня установа певного рівня і спрямування, що базується на оригінальних індивідуальних авторських засадах і має автономну форму функціонування; як унікальна одинична система педагогічних, творчих, виконавських (та інших) принципів і методів певного напряму фахової освіти; як багаторівневий комплекс роботи над прочитанням авторського тексту, що позначений неповторною своєрідністю настанов і напрацювань наставника, що передаються учневі.

17 Дедусенко Ж. Виконавська піаністична школа як рід культурної традиції : автореф. дис. ... канд. мистецтвознавства: 17.00.01. Київ, 2002. С. 7. 
Цікаво зауважити, що в основі різних аспектів діяльності школи, як гнучкої балансуючої системи взаємодії педагога й учня, є діалектика константних та динамічних елементів: учитель як носій та взірець комплексу музичного професіоналізму й учень, що переймає, реалізує i творчо переосмислює цей комплекс крізь власну особистість; певна амбівалентність із стереотипу та новації в контексті традиції (за Ю. Левадою); школи навчального закладу як носія сформованої традиції, канону та школи окремого педагога як чинника розвитку, збагачення, примноження традиції; кінцевий результат навчання концертне виконання, як співвіднесення виконавської інтерпретації (індивідуально-авторське начало) та віртуозності (як прояв особистості); співвідношення музичного професіоналізму та виконавської творчості; взаємозв'язок педагогічної, дослідницької та виконавської i композиторської діяльності; єдність і взаємозумовленість просвітництва і рівня фахової підготовки; централізація фахової освіти (педагогіки, методики, наукової діяльності, виконавської і композиторської творчості) у провідному осередку, поширення його здобутків на різні освітні рівні та види діяльності, асиміляція в інші регіональні школи зі збереженням комплексу ознак первинної моделі, охоплення концертною практикою нових національно-географічних теренів і соціальних груп цільової аудиторії; виховання, формування настанов творчої особистості та вдосконалення професійно-технічних навичок. Наведений комплекс ознак взято за основу подальшого аналізу статистичного й емпіричного матеріалу.

Індивідуальним авторським школам присвячено чимало праць, які здійснюють класифікацію діалогічних принципів взаємодії компонентів сформованої національної чи регіональної традиції $\mathrm{i}$ яскравих індивідуальних знахідок у педагогічно-інтерпретаторських концепціях, які розкривають окремі високорезультативні спрямування творчої діяльності, водночас збагачують і оновлюють наявні системи. Прикладами можуть послужити розвідки, авторами яких $є$ I. Копоть («Трубач Григорій Бєлінський та його виконавська школа»), О. Юрченко («Олена Костенко - засновниця цимбальної виконавської школи Слобожанщини»), дисертація Л. Садової «Виконавськометодичні засади фортепіанної школи Вілема Курца як джерело розвитку львівської піаністики» тощо.

Ознаками авторської школи, що реалізується в межах регіональної (зокрема, інституалізованої) $є$ наявність авторської виконавської моделі, систематична робота над поповненням навчального репертуару шляхом перекладів, аранжувань композицій провідних митців регіону, ï широке входження у практику поза його межами, визнання фахівцями, реалізація триєдності системи «школа - коледж - ЗВО». 
Актуальні на сучасному етапі дослідження регіональних інструментальних шкіл як інституалізованої форми школи в контексті локальної виконавської традиції і напрацювань інструментальної педагогіки окремого регіону. Дані проблеми розглядаються у працях I. Андрієвського, Р. Вовка, Г. Голяки, М. Давидова, В. Дутчак, В. Зайця, Є. Іванова, В. Качмарика, О. Криси, Т. Мартинюк, Т. Моргунова, I. Панасюка, О. Самойленко, А. Свєтова, В. Сидоренко, Л. Снєдкова.

Серед перспективних напрямів подальшого наукового розроблення окресленої проблематики є регіональний аспект функціонування школи, оскільки він наділений окресленою специфікою. Однак механізм цієї класифікації у своїй основі має більш синтетичну, комплексну природу. Здобутки регіональних шкіл $\epsilon$ показником активності розвитку мистецького процесу, формування і збагачення національної традиції. Так, В. Мартинюк констатує: «Найвищим надбанням української музичної культури другої половини ХX століття стали національні диригентсько-хорові школи. До найсуттєвіших компонентів їх функціонування ми відносимо джерела традиції, комплекс мистецьких та педагогічних засад і принципів у всій їх різноманітності, естетичні настанови, процеси та тенденції у виконавстві, форми організації хорових колективів, своєрідність звукового еталону епохи, розвиток музикознавчої думки в галузі хорознавства» ${ }^{18}$.

Серед перспективних напрямів подальшої наукової розробки окресленої проблематики Ж. Дедусенко відзначає також вивчення взаємодії локальних шкіл із культурною парадигмою географічних ареалів. Це твердження, безсумнівно, слушне, оскільки специфіка регіональної школи полягає в засвоєнні неповторних освітньо-фахових, педагогічних, виконавських традицій певного локального осередку, на які проєктуються здобутки i напрацювання їхніх яскравих представників, засновників авторських шкіл, що стимулюють поступ і збагачення традиції.

У контексті даної проблематики фігурують дослідження, присвячені вивченню історії української школи народно-інструментального мистецтва, М. Давидова ${ }^{19}$, окремих навчальних закладів (роботи

18 Мартинюк А. Сучасна диригентсько-хорова освіта в Україні в системі педагогічної антропології. UPL: http://www.conference.mdpu.org.ua/conf-all/confer/ 2002/conf-antro/1/martinuk.html.

19 Давидов М. Київська академічна школа народно-інструментального мистецтва : посібник. Київ : НМАУ ім. П.І. Чайковського, 1998. 224 с. ; Давидов М. Історія виконавства на народних інструментах (українська академічна школа) : підручник для вищих та середніх музичних навчальних закладів. Київ : НМАУ ім. П.І. Чайковського, 2005. 419 с. 
В. Свдокімова ${ }^{20}$, Д. Кужелєва, А. Душного ${ }^{21}$ Л. Мельник ${ }^{22}$, I. Гордельянова, А. Свєтова ${ }^{23}$ ), діяльності та творчості провідних наставників - засновників та керівників виконавських колективів, авторів аранжувань i оригінальних композицій, методичних та репертуарних збірників тощо.

\section{2. Львівська школа баянного мистецтва: регіональні типологічні особливості}

Вивчення Львівської баянної школи як виокремленого мистецького явища зі специфічними настановами, творчою традицією, напрямами реалізації i яскравими здобутками натепер має потужну базу емпіричних напрацювань: розвідки, присвячені окремим етапам, напрямам, здобуткам школи та діяльності окремих яскравих персоналій, узагальнюючі праці з історії української школи народноінструментального мистецтва М. Давидова, Є. Іванова, А. Сташевського, А. Семешка, праці М. Імханицького, довідники А. Басурманова, А. Семешка, словник I. Лисенка, праці А. Батршина, В. Балика, В. Власова, В. Голубничого, А. Душного, С. Карася, Д. Кужелєва, Е. Мантулєва, М. Оберюхтіна, А. Онуфрієнка, Я. Олексіва, Б. Пица, Л. Посікіри, М. Римаренка, А. Славича, І. Фрайта, М. Черепанина, Ю. Чумака, А. Шамігова, О. Якубова, В. Янчака й іншх. Їхні матеріали охоплюють найрізноманітнішу проблематику, пов'язану з досягненнями Львівської баянної школи у виконавстві, педагогіці, репертуарній та дидактичній творчості, ансамблевими формами музикування, творчими портретами окремих представників, що може слугувати потужним підгрунтям для виходу на певні узагальнення ${ }^{24}$.

${ }^{20}$ Евдокимов В. Одесская академическая школа народно-инструментального искусства : учебное пособие. Одесса : Астропринт, 1999. 88 с.

21 Душний А. Прикарпатський дует баяністів - творчо-виконавський аспект : навчальний посібник. Дрогобич : По́світ, 2007. 88 с. ; Душний А., Пиц Б. Кафедра музичних інструментів та вокалу Дрогобицького державного педагогічного університету імені Івана Франка : науково-історичний довідник / гол. ред. І. Фрайт. Дрогобич : По́світ, 2011. 196 с.

${ }_{22}$ Мельник Л., Бурко С. Львівська філармонія: до і після століття : науковопопулярне видання. Львів, 2006. 76 с.

${ }_{23}$ Свєтов А. Харківська баянна школа та ії видатні представники. Проблеми взаємодії мистеитва, педагогіки та теорії $і$ практики освіти : збірник наукових праць. Харків : ХДУМ ім. І. Котляревського, 2009. Вип. 25. С. 90-99.

Академічне народно-інструментальне мистецтво та вокальні школи Львівщини : збірник матеріалів Науково-практичної конференції / ред.-упоряд. : А. Душний, С. Карась, Б. Пиц. Дрогобич : По́світ, 2005. 342 с. ; Львівська баянна школа та її видатні представники (70-річчю від дня народження А. Онуфрієнка присвячується) : збірник матеріалів Науково-практичної конференції / упоряд. : 
Дослідженню даної школи присвячені праці О. Бобечко ${ }^{25}$, А. Боженського ${ }^{26}$, М. Булди, А. Душного 27 , С. Карася, Д. Кужелєва ${ }^{28}$, Б. Пица ${ }^{29}$, А. Сташевського ${ }^{30}$, I. Фрайта ${ }^{31}$, В. Шафети ${ }^{32}$, Ю. Чумака ${ }^{33}$

А. Душний, С. Карась, І. Фрайт. Дрогобич : Коло, 2005. 148 с. ; Львівська баянна школа та ії видатні представники. Михайлу Оберюхтіну присвячується : збірник матеріалів Міжнародної науково-практичної конференції / ред.-упоряд.

А. Душний, С. Карась, Б. Пиц. Дрогобич : По́світ, 2006. 160 с.

${ }^{25}$ Бобечко О. Яскравий представник Львівської баянної школи Сергій Карась. Львівська баянна школа та ї̈ видатні представники (70-річчю від дня народження А. Онуфрієнка присвячується) : збірник матеріалів Науково-практичної конференції / упоряд. : А. Душний, С. Карась, І. Фрайт. Дрогобич : Коло, 2005. С. 7-11.

26 Боженський А. Сьогодення Львівської школи народно-інструментального мистецтва. Крымские диалоги : культура, искусство, образование. Симферополь : НИЦ КИПУ, 2011. Вып. 5. С. 39-41 ; Боженський А. Творчий портрет Андрія Душного в контексті Львівської баянної школи. Проблеми удосконалення професійної підготовки фахівців мистеиьких дисииплін : збірник матеріалів Всеукраїнської відкритої науково-практичної конференції, присвяченої пам'яті А.Ф. Кречківського, м. Суми, 7-9 квітня 2011 р. Суми : Вінніченко М.Д., 2011. С. 25-28.

27 Душний А. Виконавські досягнення Львівської школи баянно-акордеонного мистецтва у 1990-2000-х роках. Народно-інструментальне мистецтво на зламі XXXXI століть : збірник матеріалів Міжнародної науково-практичної конференції, ДДПУ ім. І. Франка, 25 березня 2007 р., м. Дрогобич / ред.-упоряд. : А. Душний, С. Карась, Б. Пиц. Дрогобич : По́світ, 2007. С. 208-214 ; Душний А. Молода генерація Львівської баянної школи: творчий портрет Ярослава Олексіва. Молодь $і$ ринок. 2009. № 8 (55). С. 70-74 ; Душний А. Композиторська спадщина Анатолія Онуфрієнка : методико-виконавський зріз. Творчість композиторів Украӥни для народних інструментів : збірник матеріалів Науково-практичної конференції, м. Львів, ЛДМА ім. М. Лисенка, 10 квітня 2006 р. / ред.-упор. : А. Душний, Б. Пиц, С. Карась. Дрогобич : По́світ, 2006. С. 41-45 ; Душний А. «Прикарпатський дует баяністів» : різнояскраві грані мистецького ансамблю крізь призму спільності художньої мети. Львівська баянна школа та ї̈ видатні представники. Михайлу Оберюхтіну присвячується : збірник матеріалів Міжнародної науково-практичної конференції / ред.-упоряд. : А. Душний, С. Карась, Б. Пиц. Дрогобич : По́світ, 2006. С. 124-131 ; Душний А., Чепак С. Виконавське сьогодення Львівської баянної школи в контексті українського академічного народно-інструментального мистецтва. Актуальні питання баянно-акордеонного виконавства та педагогіки в мистецьких навчальних закладах / ред.-упоряд. та відп. за вип. А. Сташевський. Луганськ : Поліграфресурс, 2010. Вип. 4. С. 22-28 ; Душний А. Компонування творчості для бандури представниками Львівської баянної школи в контексті національної соціокультури. Молодь і ринок. 2012. № 5 (88). С. 66-80.

28 Кужелєв Д. Про педагогічну майстерність М.Д. Оберюхтіна. Академічне народно-інструментальне мистецтво та вокальні иколи Львівщини : збірник матеріалів Науково-практичної конференції / ред.-упоряд. : А. Душний, С. Карась, Б. Пиц. Дрогобич : По́світ, 2005. С. 152-159.

${ }^{29}$ Пиц Б. Невідомий представник Львівської баянної школи. Львівська баянна школа та ї̈ видатні представники (70-річчю від дня народження А. Онуфрієнка присвячується) : збірник матеріалів Науково-практичної конференцій / упоряд. : А. Душний, С. Карась, І. Фрайт. Дрогобич : Коло, 2005. С. 88-97 ; Пиц Б. Петро Рачинський: штрихи до творчого портрета. Академічне народно-інструментальне мистецтво та вокальні школи Львівщини : збірник матеріалів Науково-практичної 
й інших, у яких розглядаються педагогічна спадщина, виконавські досягнення, творчість та наукові напрацювання ії представників.

Вагомим науковим напрацюванням у цьому напрямі постає дослідження С. Карася «Інтерпретація музики бароко на баяні (теоретико-виконавський аспект)» (м. Львів, 2006 рік), що розвиває традиційний для Львівської академічної баянної школи аспект наукового зацікавлення. Тут у контексті аналізу виконавських завдань подано компаративне зіставлення прочитань перекладу клавірного твору Й.С. Баха Я. Олексівим (представник баянного класу С. Карася й Я. Ковальчука) та І. Квашевічем (Білорусь), позначені індивідуальною творчою концепційністю, рельєфністю, органічним сполученням раціональної та художньо-експресивної сторін. У дослідженні науковець приходить до висновку, який характеризує суголосність тенденцій у галузі інтерпретації Львівської баянної школи: «Сучасне баянне виконавство сягає перспективного рівня узагальнення, синтезу, органічного сплаву колишніх інтерпретаційних моделей,

конференції / ред.-упоряд. : А. Душний, С. Карась, Б. Пиц. Дрогобич : По́світ, 2005. С. 176-182 ; Пиц Б. Музичні пріоритети Володимира Балика. Львівська баянна школа та ї̈ видатні представники. Михайлу Оберюхтіну присвячується : Збірник матеріалів Науково-практичної конференції / ред.-упоряд. : А. Душний, С. Карась, Б. Пиц. Дрогобич : По́світ, 2006. С. 20-32.

${ }_{30}$ Сташевський А. Творчість Володимира Балика і нові тенденції української музики для баяна 1980-х років. Львівська баянна школа та ї̈ видатні представники (70-річчю від дня народження А. Онуфрієнка присвячується) : збірник матеріалів Науково-практичної конференції / упоряд. : А. Душний, С. Карась, І. Фрайт. Дрогобич : Коло, 2005. С. 111-115 ; Сташевський А. Творчість композиторів Львівщини для баяна. Академічне народно-інструментальне мистецтво та вокальні школи Львівщини : збірник матеріалів Науково-практичної конференції / ред.-упоряд. : А. Душний, С. Карась, Б. Пиц. Дрогобич : По́світ, 2005. С. 203-209.

${ }_{31}$ Фрайт I. Корифеї баянного мистецтва на Дрогобиччині. Львівська баянна школа та ї̈ видатні представники (70-річчю від дня народження А. Онуфрієнка присвячується) : збірник матеріалів Науково-практичної конференції / упоряд. : А. Душний, С. Карась, I. Фрайт. Дрогобич : Коло, 2005. С. 116-123.

32 Шафета В. Виконавські склади та репертуар мішаних баянних ансамблів Львівщини. Музикознавчі студї інституту мистеитв Волинського національного університету імені Л. Українки та Національної музичної академії України імені П.І. Чайковського : збірник наукових праць / упоряд. О. Коменда. Луцьк : Волин. нац. ун-т ім. Лесі Українки, 2010. Вип. 6. С. 145-154.

33 Чумак Ю. Внесок Віктора Власова в науково-мистецький проєкт «Львівська школа баянно-акордеонного мистецтва». Творчість композиторів Украӥни для народних інструментів : збірник наукових праць молодих учених Дрогобицького державного педагогічного університету імені Івана Франка : матеріали II-ї Всеукраїнської науково-практичної конференції, присвяченої 75-річчю від дня народження видатного українського композитора Віктора Власова, м. Дрогобич, 2 грудня 2011 року / ред.-упоряд. А. Душний. Дрогобич : РВВ ДДПУ ім. І. Франка, 2011. Вип. 2. С. 76-82. 
запропонованих піаністами. Розмаїті виконавські версії репрезентують закономірний поступ у безперервній естафеті інтерпретації музики Баха - своєрідний креативний синтетизм» ${ }^{34}$.

Кониертне виконавство й участь у конкурсно-фестивальному русі окремих колективів чи провідних представників Львівської баянної школи в їхньому складі висвітлюють статті публіцистичного характеру, рецензії та відгуки в періодичних виданнях («Музика», «Радянське слово», «Радянський педагог», «Франківець», «Галицька зоря», «Вільне слово», «Прикарпаття»), довідникова література (довідники А. Басурманова, А. Семешка, А. Мірека, словник І. Лисенка тощо).

Цінними виданнями, які містять докладні статистичні дані, стали новітні довідники: «Львівська школа баянно-акордеонного мистецтва» (м. Дрогобич, 2010 рік), «Кафедра народних музичних інструментів та вокалу Дрогобицького державного педагогічного університету імені Івана Франка» (м. Дрогобич, 2011 рік) А. Душного та Б. Пица, «Баянноакордеонне мистецтво України на зламі XX-XXI століть» (м. Тернопіль, 2009 рік) А. Семешка.

Науково-дослідницька сфера в галузі баянного мистецтва традиційно охоплює коло проблем, пов'язаних із теорією й історією виконавства, а також із педагогікою (роботи І. Алексєєва, М. Давидова, Ю. Бая, В. Самітова, С. Жукова, С. Іванова, Д. Кужелєва, Д. Юника й інших).

Важливу групу становлять праці, у яких закладено традииії аналізу баянної творчості - перекладної й оригінальної, оскільки, як слушно зазначає А. Сташевський, «питання дослідження оригінального репертуару, зокрема творчості вітчизняних композиторів, є аспектом постійно актуальним, що потребує пояснення закономірностей сприйняття творів даної галузі музичного мистецтва» ${ }^{35}$. У його дослідженні висвітлюється стан баянної музики сучасних композиторів, серед яких В. Зубицький, В. Рунчак, Ю. Шамо, В. Власов, А. Білошицький, О. Щетинський та інші.

Сюїта й партита у творчому доробку українських митців розглядаються в дисертації Я. Олексіва «Рецепція жанрів сюїти i партити в українській баянній музиці другої половини ХХ століття» ${ }^{36}$ (м. Львів, 2011 рік). У цій роботі здійснено аналіз низки композицій

${ }^{34}$ Карась С. Інтерпретація музики бароко на баяні : теоретико-виконавський аспект : дис. ... канд. мистецтвозн.: 17.00.03. Львів, 2006. 255 с.

35 Сташевський А. Баянне мистецтво України: тенденції розвитку оригінальної музики та індивідуальне втілення жанрово-стильового аспекту у творчості Володимира Рунчака : автореф. дис. ... канд. мистецтвозн.: 17.00.03. Київ, 2004. 19 с.

${ }^{36}$ Олексів Я. Рецепція жанрів сюїти і партити в українській баянній музиці другої половини XX століття : дис. ... канд. мистецтвозн.: 17.00.03. Львів, 2011. 234 с. 
митців-баяністів, що представляють Львівську баянну школу. Вона представлена такими творами, як сюїтний цикл «Співанки» № № 1, 2, 3 (1987 рік), цикл «Маленька сюїта» А. Онуфрієнка, Дитячий альбом «Прикарпатські візерунки» Е. Мантулєва, Сюїта № 1 «Ескізи» О. Колосовської (2009 рік), «Дитячий альбом баяніста (акордеоніста)» № 1 (2007 рік), «Дитячий альбом баяніста (акордеоніста)» № 2 (2010 рік) В. Шлюбика, численні композицій В. Власова.

$\mathrm{y}$ численних публікаціях щодо творчих портретів окремих представників баянної традиції Львівщини епізодично і принагідно висвітлюються композиторські здобутки педагогів-практиків, творців дидактичної літератури, виконавського репертуару навчальних колективів: А. Онуфрієнка, Я. Олексіва (А. Душний ${ }^{37}$, І. Куртий ${ }^{38}$ ), Е. Мантулєва (А. Славич), Б. Гурана, В. Балика, А. Батршина (Б. Пиц), Р. Ілика (М. Михаць), М. Оберюхтіна (В. Балик, А. Батршин, В. Голубничий, Д. Кужелєв, М. Римаренко, Б. Пиц, Р. Кундис).

Аспекти опосередкування фольклорного матеріалу в окремих композиціях львівських митців аналізуються в дисертації київського науковця А. Шамігова «Особливості опосередкування фольклору в оригінальній музиці українських композиторів для баяна соло (фольклорний неоромантизм, неофольклоризм, нова фольклорна хвиля)» (м. Київ, 2011 рік) ${ }^{39}$. У контексті висвітлення проблеми автор аналізує цикл «Прикарпатські візерунки» $\mathrm{i}$ «Танець 3 топірцями» Е. Мантулєва, «Танець 3 полонини» А. Онуфрієнка, «Дві п’єси на воронезькі народні пісні» А. Батршина, «Парафраз на тему української народної пісні «Сусідка»» М. Корчинського, «Рапсодію» А. Онуфрієнка, «На поточку» К. Соколова (аранжування А. Душного), а також твори В. Власова. Наявність цього репертуарного багажу в полі

37 Душний А. Композиторське напрацювання Анатолія Онуфрієнка в контексті становлення репертуару для народних інструментів. Молодь і ринок. 2010. № 4 (63). C. 30-35 ; Душний А. Львівські народно-інструментальні традиції. Наша культура : Вісник Старосамбірського районного Народного дому. 2009. Квітень. Ч. 2.

38 Куртий I. До питання стильових особливостей доробку А. Онуфрієнка, В. Балика, Я. Олексіва в еволюційному просторі Львівської баянної школи. Творчість композиторів Украӥни для народних інструментів : збірник наукових праць молодих учених Дрогобицького державного педагогічного університету імені Івана Франка : матеріали II-ї Всеукраїнської науково-практичної конференції, присвяченої 75-річчю від дня народження видатного українського композитора Віктора Власова, ДДПУ ім. І. Франка, 2 грудня 2011 року, м. Дрогобич / ред.упоряд. А. Душний. Дрогобич : РВВ ДДПУ ім. І. Франка, 2011. Вип. 2. С. 47-52.

39 Шамігов А. Особливості опосередкування фольклору в оригінальній музиці українських композиторів для баяна соло (фольклорний неоромантизм, неофольклоризм, нова фольклорна хвиля) : автореф. дис. ... канд. мистецтвозн.: 17.00.03. Київ, 2011. 17 с. 
наукового зацікавлення поза межами регіону свідчить про його художню і наукову цінність у професійно-виконавській сфері.

Отже, актуальність проблематики виокремлення, наукової і статистичної аргументації й обгрунтування Львівської баянної школи як самодостатньої і повноцінної регіональної школи за наявними еволюційними процесами, ознаками і складовими частинами зумовила формування потужного масиву розрізнених $\mathrm{i}$ різнопланових напрацювань, що створюють достатне підгрунтя для виходу на наукове узагальнення.

Особливістю регіональної школи є іiі проміжне положення між явищами загальнонаціонального масштабу i локальними сферами реалізації з налагодженою системою двосторонніх взаємозв'язків. Формування регіональної школи тісно пов'язане 3 основними фаховими осередками країни.

Зворотний зв'язок реалізується через успіхи представників регіональних шкіл на міжнародних конкурсах, їхню концертногастрольну практику, реалізацію аудіозаписів, які засвідчують зрілість i перспективність педагогіко-методичних принципів національної школи загалом, сприяють популяризації українського оригінального та перекладного баянного репертуару на світових теренах.

Виходячи 3 вищевикладеного, варто конкретизувати позицію локального, регіонального осередку баянного інструменталізму як дочірнього і похідного від загальнонаціонального, а одним із базових $\epsilon$ показник наявності в її лоні результативних авторських шкіл.

Утвердження баянного мистецтва у статусі складової частини академічної музичної культури в кожному 3 його регіональних осередків позначене своєрідністю. Воно зумовлюється геополітичними чинниками, характером культурного обміну зі світовими центрами баянно-акореонного виконавства, закоріненістю традицій гармошкового музикування в побутовій культурі міста, його поширення в народно-інструментальній традиції, залученням до концертно-виконавської практики видатних місцевих музикантів.

Проте аналіз його генези дає підстави зауважити деякі спільні тенденції. М. Булда слушно стверджує, що в українському акордеоннобаянному виконавстві довоєнного періоду співіснували дві тенденції, «одна 3 яких бере початок від народних гулянь, інша - піднімається до філармонічного мистецтва» ${ }^{40}$.

На теренах Східної України поширення гармонік відбувається в руслі тенденцій Російської імперії, набуває системного характеру наприкінці XIX - на початку XX століття (фабрика К. Міщенка

40 Булда М. Професійне становлення та розвиток виконавської творчості вітчизняних і зарубіжних естрадно-джазових акордеоністів-баяністів 1920-1940 років. UPL: http://www.nbuv.gov.ua/portal/Soc_Gum/Vpu//2008_14/statti/Bulda.pdf. 
в Харкові з 1903 року виготовляла не лише діатонічні гармоніки, а згодом і хроматичні інструменти за системою Мірвальда - власне баяни, не лише 3 готовою, але й виборною системами). У 19201930-х роках популярність баяна набуває значного масштабу й підтримується державою, розгортають діяльність численні державні підприємства 3 виготовлення язичкових клавішно-пневматичних інструментів (з 1931 року в Києві та Харкові, 31933 року у Кремінному, 31934 року - у Житомирі). Баян уособлює ідею «народності» музичного мистецтва в радянській ідеології, яке мало демонструвати забезпечення культурних запитів найширших мас, орієнтованих на широкий самодіяльний рух.

Натомість Львівщина є регіоном, де як фольклорна, так і академічна традиція баянного виконавства практично відсутні до середини 1940-х років. У міський побут та розважальну сферу регіону дещо раніше був привнесений акордеон, безпосередньо через чеськоавстрійські впливи в XIX столітті, оскільки Галичина належала до імперії Габсбургів. Ці «внутрішні впливи» були доповнені зовнішніми - французькими, на початку XX століття. Звідси традиція виконання проникла у фольклорні форми. Дослідники музичного інструментарію карпатського регіону констатують наявність та масове поширення у весільних капелах Гуцульщини чеської гармонікигелігонки (діатонічний кнопковий акордеон), акордеона, а також вказують на значущість цих інструментів у побуті та дозвіллі. Це виокремлює формування традиції виконавства на гармоніці Західноукраїнського регіону через специфіку генези - прямого контакту з європейськими виконавськими осередками, без типової для інших регіонів України складової частини: трансформації цієї традиції на російському грунті.

Натомість у сфері естрадно-розважального мистецтва акордеон, як ансамблевий інструмент, був поширений із 1920-х років, будучи орієнтований на європейські та джазові американські тенденції цього напряму музичного мистецтва. Дослідники суміжних проблем фіксують у документах наявність акордеонів у складах Капели Леоніда Яблонського, джаз-оркестрів та джаз-ансамблів у структурі театрів естрадних мініатюр («Театр малих форм», «Золотий усміх», «Веселий Львів» тощо), кабаре та казино, естрадних ревю, оперети ${ }^{41}$. У радянський час акордеон використовували новостворені колективи i театри розважальної сфери: популярного в 1930-1940-х роках оркестру

${ }^{41}$ Шафета В. Баян та акордеон у складі естрадних і фольклорно-орієнтованих професійних та самодіяльних колективів. Науковий вісник Національної музичної академії Украӥни імені П.І. Чайковського : Музичне виконавство $і$ педагогіка : історія, теорія, інтерпретаційні аспекти композиторської творчості / авт. проєкту, ред.-упоряд. : М. Давидов, В. Сумарокова. Київ : НМАУ, 2011. Вип. 96. С. 272-279. 
«Теа-джаз» під орудою Григорія (Сжи) Варса, Львівського державного (обласного) театру естради і мініатюр (І. Ковальов) та філармонічного ансамблю оперети під керуванням Фелікса Мухи, заснованого в 1946 році (пізніше він став називатися «Львівська естрада») ${ }^{42}$. Цей ракурс концертної діяльності загалом суголосний загальноукраїнським тенденціям, вирізняється безпосередністю включення в європейський контекст, зумовленою географічним положенням регіону та притаманним йому полікультуралізмом суспільної організації.

Подальша сфера функціонування баянів-акордеонів у радянську добу, за стабільного збереження їх у сфері естрадно-ансамблевої музики (баян фігурує в них поряд з акордеоном), поширюється в академічну практику через мережу навчальних закладів, а вже звідти у колективи художньої самодіяльності, згодом баян, поряд 3 акордеоном, входить у сферу народно-інструментального музикування фольклорної традиції.

Хронологічно першим фаховим музичним закладом, де було розпочато викладання гри на народних інструментах, у Західноукраїнському регіоні було Львівське державне музичне училище. На об'єднаному оркестровому відділі (зав. відділом професор О. Москвичів) було відкрито класи народних інструментів: у 1945 році - бандури (викл. М. Грисенко), у 1946 році - акордеона (викл. О. Пільщиков - випускник Київського музичного технікуму) ${ }^{43}$. Однак 3 ідеологічних причин викладання гри на акордеоні тривалий час був загальмоване у процесі своєї професіоналізації. «Всьому виною була горезвісна постанова ЦК ВКПб від 1949 року «Про оперу В. Мураделі «Велика дружба»», у якій нищівної критики зазнав «космополітизм у мистецтві», де гітара (як акордеон і концертіно) була визнана «буржуазним» інструментом і вигнана зі стін вищих навчальних закладів» ${ }^{44}$ (переклад з рос. мій $-P$. K.).

У повоєнний період - від вересня 1947 року у ЛДМУ відкрито клас баяна (очевидно, сам факт відкриття класу баяна уособлював ідеологічний тиск на систему регіональної музичної освіти) завдяки призначенню завідувачем відділу народних інструментів Г. Казакова, за ініціативою якого створюються ансамблі й оркестр народних інструментів із баянами у складі (керівники : Г. Казаков, В. Дзиндра,

${ }^{42}$ Мазепа Л., Мазепа Т. Шлях до музичної Академії у Львові : у 2-х т. Львів : Сполом, 2003. T. 1. С. 47.

43 Давидов М. Історія виконавства на народних інструментах (українська академічна школа) : підручник для вищих та середніх музичних навчальних закладів. Київ : НМАУ ім. П.І. Чайковського, 2005. С. 76 ; Львівське державне музичне училище імені Станіслава Людкевича. Сторінки історії / ред.-упоряд. Н. Пузанкова. Львів : ТеРус, 2009. С. 16.

44 «Самое главное - находить новые вещи, иногда подживлять репертуар» : интервью с Н. Михайленко. Гитаристъ. 2005. № 1. С. 19. 
П. Шахов, С. Лазарчук, Л. Дражниця, М. Колєсніков, Є. Дацина). Нині керівником оркестру є народний артист України О. Личенко.

У 1946 році згідно з постановою Комітету у справах мистецтва УРСР було відкрито класи народних інструментів у Львівській державній консерваторії ім. М. Лисенка, серед яких і баянний, який відтепер охоплює всі ланки й етапи фахової підготовки. «Факт відкриття класу баяна у Львівській консерваторії $<\ldots>\epsilon$ найяскравішим свідоцтвом неймовірно стрімкого проникнення баяна в середовище народних інструментів нового для себе регіону - Західної України, навіть більше, його офіційного закріплення в родині цих народних інструментів навіть на рівні академічної освіти», - зазначає Л. Понікарова ${ }^{45}$. Класи акордеона, баяна та домри при оркестровій кафедрі очолив випускник Київської консерваторії 1946 року (клас М. Геліса), лауреат Всесоюзного конкурсу виконавців на народних інструментах (1939 рік) Георгій Казаков. Він став засновником та керівником ансамблів народних інструментів, а також оркестру народних інструментів домрово-балалаєчного типу з репертуаром, який відповідав вимогам академізації народних інструментів у вищих навчальних закладах (до репертуару цих ансамблів входили: увертюра «Прометей» Л. Бетховена, «Концерт-поема для баяна 3 симфонічним оркестром» А. Рєпнікова (у перекладі), твори 3. Паліашвілі, К. Караєва, А. Онуфрієнка, Н. Плаксюка). Цьому музиканту регіон завдячує заснуванням академічного народно-інструментального музикування колективних форм, що підготувало грунт для виокремлення баянного класу в самостійну дисципліну на рівні академічного вишу, він взяв на себе винятково складні завдання забезпечення інструментарієм, виконавським репертуаром та розбудови фахової освітньої системи за вертикаллю згори вниз (відкриваючи класи баяну в консерваторії - у 1946 році, музичному училищі - у 1947 році та, згодом, у музичних школах), за горизонталлю (зв'язки 3 педагогами суміжних кафедр, створення виконавських колективів, навчальних програм та методичної бази).

У 1950 році до роботи на відділі було запрошено В. Запорожця та М. Оберюхтіна - випускників Київської консерваторії, послідовників М. Геліса.

Засади авторської школи М. Геліса, що набула загальнонаціонального значення в контексті академізації народноінструментального мистецтва України, послужили основою $\mathrm{i}$ для становлення баянної традиції Львівщини. Вони представлені, продовжені і розвинуті багатогранною і плідною діяльністю його учнів:

45 Поникарова Л. Баян в народно-инструментальном жанре Украины : учебнометодическое пособие по курсу «Теория и история народно-инструментального исполнительства». Харьков : Торнадо, 2003. С. 69. 
Г. Казакова, М. Оберюхтіна (родоначальник школи академічного баянного мистецтва Львівщини), В. Запорожця, В. Воєводіна.

Так, біля основ формування фахового професіоналізму, педагогічнометодичних принципів та виконавської традиції був вихованець класу М. Геліса в Київській консерваторії, музикант-мультиінструменталіст (домрист за основною освітою) $Г$. Казаков. Він постає як основоположник професіоналізму народно-інструментальної освіти регіону, засновник спеціальних народно-інструментальних класів у музичному училищі (1947 рік) та консерваторії (1946 рік) Львова, організатор, учасник та диригент перших ансамблів, ініціатор концертної, теоретичної, творчої діяльності в галузі народноінструментального мистецтва, автор численних творів навчального репертуару. Своєю діяльністю він сформував основу традиції та підготував грунт для функціонування авторської школи баянного мистецтва, започаткованої М. Оберюхтіним.

Дана школа виховала: низку професійних музикантів - лауреатів конкурсів найвищих рівнів. Серед таких наймасштабніше представлені вихованці класів М. Оберюхтіна (1960-1970-ті роки), А. Онуфрієнка (1980-ті роки), Д. Кужелєва, С. Дацини, Е. Мантулєва (1990-ті - поч. 2000-х років), у сучасності - Я. Ковальчука, С. Карася, А. Душного, Я. Олексіва, В. Іванця, Ю. Чумака, ансамблеві колективи за участю чи під керівництвом Е. Мантулєва, В. Чумака, С. Максимова, П. Рачинського, О. Личенка, Я. Олексіва, В. Гамара, В. Янчака, В. Шафети, Р. Капранова, А. Яворівського, М. Головчака й інших.

\section{ВИСНОВКИ}

Львівський осередок баянного мистецтва сформувався шляхом засвоєння й адаптації до унікальних регіональних умов мистецькопедагогічних засад авторської школи М. Геліса, привнесених у музичну традицію краю його учнями і послідовниками. Ключовим чинником у цьому процесі стала реалізації авторської школи баянного мистецтва М. Оберюхтіна, розвинута в систему оригінальних авторських шкіл його вихованців. Сьогодні Львівська баянна школа наділена всім необхідним комплексом ознак та параметрів, необхідних для іiі дефініції як сформованої регіональної інструментальної школи. Їй повною мірою притаманні: етапність освітніх та мистецьких напрацювань регіонального спрямування, автономність специфіки; тяглість і спадкоємність у формуванні іï традиції; наявність мережі осередків плекання баянноакордеонного академічного мистецтва та наявної в них системи яскравих індивідуально-авторських шкіл зі спадкоємністю провідних векторів діяльності; комплексність реалізації методико-педагогічних, виконавських та творчих засад; кількість, вагомість, стабільність здобутків і 
результативності на регіональному, національному та міжнародному рівнях; перспективність подальшого розвитку.

Специфіка Львівської баянної школи як регіональної полягає в її функції показника активності розвитку як локальних мистецьких процесів, так і чинника формування і збагачення національної традиції. Вона демонструє як виконавський, так і педагогічний аспекти реалізації.

Результативність школи підтверджена численними успіхами виконавців, що пройшли стадію формування виконавського досвіду під керівництвом наставників - представників даної школи, на конкурсах різних рівнів. Авторитетність суспільно-громадянської, етичної, мистецької позиції засвідчує спадкоємність активності вихованців школи у пріоритетних видах творчої, виконавської, наукової, краєзнавчої діяльності, їх залучення до широкої сфери напрямів самореалізації, дотичних до фахової освіти та практичного виконавського досвіду, спрямовану на просвітництво, навчання, спадкоємність у передачі традиції фахових засад.

\section{АНОТАЦІЯ}

Стаття присвячена уніфікації й ієрархічній системі наукового (категоріальний, термінологічний, типологічний тощо) апарату, його змістового наповнення, ознак, структури, кола функцій, які істотно відрізняються у працях різних дослідників. Вона містить позиціонування понятійного апарату як основи базової концепції дослідження, необхідної для визначення позицій, особливостей, параметрів, показників, векторів діяльності та ліній спадкоємності регіональної школи й окремих авторських шкіл як її складових частин.

Нами розкриваються горизонти дослідження Львівської баянної школи 3 позиції регіональної виконавської школи. На основі наукових визначень понять регіональної, авторської, наукової школи окреслено формулу щодо пріоритетності соціокультурного призначення, становлення та розвитку Львівської школи баянно-акордеонного мистецтва.

Доказовими аргументами функціонування регіональної баянної школи виступають тяжіння передачі авторських концепцій у трьох аспектах: спадкоємності педагогічних та виконавських принципів у поколіннях педагогів-наставників; у розгортанні позицій школи у глибину (триєдність педагогічних ланок «школа - коледж - заклад вищої освіти»); у розвитку установчих засад школи вшир (діяльність учнів-послідовників у містах і селах регіону, їх концертування та викладання поза регіоном, на теренах України та за кордоном). 


\section{SUMMARY}

The article is devoted to unification and the hierarchical system of science (categorical, terminological, typological, etc.) apparatus, its content, signs, structures, range of functions, which differ significantly in the works of different researchers. It contains the positioning of the conceptual apparatus as the basis of the basic concept of the study, necessary to determine the positions features, parameters, indicators vectors of activity and lines of succession of the regional school and individual author's schools as its components.

We reveal the horizons of the study of the Lviv Bayan School from the standpoint of the regional executive school. Based on scientific definitions of regional, author's, scientific school outlined the formula on the priority of socio-cultural purposes, formation and development of the Lviv School of Bayan-Accordion Art.

Lviv Bayan School was formed by mastering and adaptation to the unique regional conditions of the artistic and pedagogical principles of M. Gelis, introduced into the musical tradition of the region by his students and followers. A key factor in this process was the implementation of the M. Oberyukhtin author's school of accordion art, developed into a system of original author's schools of his pupils. Today, Lviv Bayan School is endowed with all the necessary set of features and parameters, necessary for its postulation as an established regional instrumental school.

Evidential arguments for the functioning of the regional bayan school there is an attraction to the transfer of authorial concepts in three aspects: continuity of pedagogical and performing principles in generations of teachers-mentors; in the deployment of school positions in depth (trinity of pedagogical units: School - College - Institution of Higher Education); in the development of the founding foundations of the school in breadth (activities of students of followers in the cities and villages of the region, their concerts and teaching outside the region, on the territory of Ukraine and abroad).

The activity of numerous prominent representatives of the Lviv Bayan School convincingly proves its originality and the progressive realization of personality in the context of the formed regional didactic and interpretive principles, their attraction and succession of activities both nationally, and on the international level.

The activities of numerous prominent representatives of the school convincingly demonstrate the uniqueness, originality and progressive realization of personality in the context of traditions, their longevity and prospects in the areas of work over the realization of the potential of performing skills, which has received international recognition, contribution to the development of the latest scientific and methodological developments, educational repertoire and concert translation and the original bayan 
repertoire, continuity of traditions of the author's school in the activities of its followers in Ukraine, so abroad.

Lviv Bayan School fully inherent in: stages of educational and artistic achievements of the regional direction, autonomy of specificity; longevity and heredity in the formation of its tradition; the presence of a network of centers for the cultivation of bayan-accordion academic art and their existing system of bright individual-author schools with continuity of leading vectors of activity; the complexity of the implementation of methodological and pedagogical, performing and creative principles; quantity, significance, stability of achievements and performance at the regional, national and international levels; prospects for further development.

Thus, confirmation of these provisions is available in the disclosure of the leading figures of the Lviv Bayan School, which laid the foundations of the system of pedagogical principles and principles of forming an instrumentalist-performer, teacher, composer, music scholar and activist, research of the leading aspects of realization of bright representatives, teachers-innovators, who teach art to the younger generation at the present stage, using the latest techniques, highly professional repertoire and a wide range of capabilities of the modern bayan and the accordion.

\section{ЛІТЕРАТУРА}

1. Давидов М. Історія виконавства на народних інструментах (українська академічна школа) : підручник для вищих та середніх музичних навчальних закладів. Київ : НМАУ ім. П.І. Чайковського, $2010.592 \mathrm{c}$.

2. Душний А., Кундис Р. Авторська школа Михайла Оберюхтіна в контексті баянного мистецтва Львівщини. Вісник Луганського начіонального університету імені Тараса Шевченка : Педагогічні науки. Серія «Мистеиька освіта: історія, теорія, практика». 2016. № 2 (299). С. 99-113.

3. Душний А., Кундис Р. Провідні авторські баянні школи України як визначальний складник регіональної інструментальної традиції. Актуальні питання гуманітарних наук : міжвузівський збірник наукових праць молодих учених Дрогобицького державного педагогічного університету імені Івана Франка / ред.-упоряд. : М. Пантюк, А. Душний, I. Зимомря. Дрогобич : Видавничий дім «Гельветика», 2020. Вип. 30. Т. 1. С. 148-154.

4. Душний А., Пиц Б. Львівська школа баянно-акордеонного мистецтва : довідник. Дрогобич : По́світ, 2010. 216 с.

5. Кундис Р. Львівська школа баянної гри 3 позицій типологічних ознак регіональної виконавської школи. Педагогічні науки: теорія, історія, інноваиійні технології. Суми : СумДПУ, 2010. № 7 (9). C. $283-290$. 
6. Львівська баянна школа та іiї видатні представники (70-річчю від дня народження А. Онуфрієнка присвячується) : збірник матеріалів Науково-практичної конференції / упоряд. : А. Душний, С. Карась, I. Фрайт. Дрогобич : Коло, 2005. 148 с.

7. Львівська баянна школа та ii видатні представники. Михайлу Оберюхтіну присвячується : збірник матеріалів Науково-практичної конференції / ред.-упоряд. : А. Душний, С. Карась, Б. Пиц. Дрогобич : По́світ, 2006. $160 \mathrm{c}$.

8. Львівське державне музичне училище імені Станіслава Людкевича. Сторінки історії / ред.-упоряд. Н. Пузанкова. Львів : ТеРус, 2009. $216 \mathrm{c}$.

9. Мазепа Л., Мазепа Т. Шлях до музичної Академії у Львові : у 2-х т. Львів : Сполом, 2003. Т. 1. 288 с.

10. Пыц Б. Научно-практическая конференция «Львовская баянная школа и ее выдающиеся представители». Народник. 2005. № 2. C. 36-37.

11. Шафета В. Внесок керівників ансамблів народних інструментів Львівщини у виконавський репертуар, музичну науку і публіцистику. Наукові записки Тернопільського начіонального педагогічного університету імені В. Гнатюка. Серія «Мистеитвознавство». 2010. № 1. C. 110-114.

12. Dushniy A. Priorities of work of Western Ukraine bayan-accordion players in the twenty first century: analysis and unification. The role of culture and art in social and humanitarian development of modern society: collective monograph / A. Dushniy et al. Lviv ; Toruń : Liha-Pres, 2019. P. 1-17.

\section{Information about the authors:} Kundys R. Yu., Candidate of Art History, Ukraine Pop Art Honored Worker, Associate Professor at the Department of Directing and Choreography Ivan Franko National University of Lviv 1, University str., Lviv, 79000, Ukraine

Dushniy A. I.,

Candidate of Pedagogical Sciences, Associate Professor, Ukraine Pop Art Honored Worker, Corresponding Member of the Teacher Education International Science Academy, Head of the Department of Folk Musical Instruments and Vocals Drohobych Ivan Franko State Pedagogical University 24, I. Franko str., Drohobych, Lviv region, 82100, Ukraine Zavialova O. K.,

Doctor of Arts, Professor, Head of the Department of Fine Arts, Musicology and Cultural Studies, Sumy Makarenko State Pedagogical University 